\title{
Case Report \\ Fecal Scrotal Abscess Secondary to Spontaneous Retroperitoneal Perforation of Ascending Colon
}

\author{
Akshay Bahadur ${ }^{D},{ }^{1}$ Nirmala Singh, ${ }^{2}$ Mayank Kashmira, ${ }^{1}$ Ashish Shukla, ${ }^{1}$ Vikas Gupta, \\ and Shashank Jain ${ }^{3}$ \\ ${ }^{1}$ Department of General Surgery, Dr. Hedgewar Arogya Sansthan, Delhi, India \\ ${ }^{2}$ VVWC-CGHS, Delhi, India \\ ${ }^{3}$ Nishkam Imaging Solution Pvt. Ltd., Delhi, India
}

Correspondence should be addressed to Akshay Bahadur; drakshay@live.com

Received 24 January 2021; Revised 8 March 2021; Accepted 11 March 2021; Published 30 March 2021

Academic Editor: Simon Ching Shun Kao

Copyright ( $) 2021$ Akshay Bahadur et al. This is an open access article distributed under the Creative Commons Attribution License, which permits unrestricted use, distribution, and reproduction in any medium, provided the original work is properly cited.

\begin{abstract}
Introduction. Fecal abscess or enterocutaneous fistulas of the scrotum are rare and are invariably the result of incarcerated bowel loop in inguinal hernia. Spontaneous perforation of the colon (SPC) having no definite cause is also rare. Much rarer is posterior colonic perforations causing an extensively large retroperitoneal abscess. Similarly, spread of retroperitoneal abscess to the thigh or scrotum has rarely been reported. We report a case of spontaneous posterior perforation of ascending colon resulting in large retroperitoneal abscess eventually causing scrotal abscess, which resolved on conservative treatment and drainage of the scrotal fecal abscess. Case Presentation. A 20-year-old male presented with gradually increasing noncolicky pain right side abdomen with nonprojectile vomiting, obstipation, and progressive abdominal distension. Clinically, the abdomen was tender with guarding over the right side with signs of inflammation on the right side back with no associated hernia. On conservative treatment, he was gradually improved but developed right side scrotal abscess a week later. CT abdomen showed a large retroperitoneal collection having multiple internal air lucencies, displacing ascending colon and caecum medically with discontinuity in the posterior wall of ascending colon. The large retroperitoneal collection was extending from right pararenal and posterior perihepatic soft tissue planes to the right iliac fossa and thigh. On drainage of the scrotal abscess, about $350 \mathrm{ml}$ of fecal contents was evacuated. The patient gradually recovered and was discharged on conservative treatment with an uneventful 4-year follow-up. Conclusion. Diagnosis of retroperitoneal perforation of the colon is often delayed due to the absence of peritoneal irritation. An extensively large retroperitoneal abscess may spread the infection to the scrotum and thigh due to extreme pressure, possibly by dissecting away the transversalis fascia through a deep ring along the side of the spermatic cord. Timely performed CT/MRI can avoid delay in the diagnosis of retroperitoneal abscess and further spread of infection.
\end{abstract}

\section{Introduction}

Enterocutaneous fistula of the scrotum is rare [1] and is almost exclusively due to incarcerated bowel loop in inguinal hernia. Spontaneous perforation of the colon (SPC) is rare $[2,3]$ and is defined as perforation of a normal colon without any contributing factor such as disease of the bowel or hernia [3]. The retroperitoneal colonic perforations are rare causes of a retroperitoneal abscess and are exclusively seen in frail elderly patients
[4]. No case of spontaneous retroperitoneal perforation of ascending colon causing an abscess or enterocutaneous fistula of the scrotum in the absence of hernia has been ever reported to the best of our knowledge in indexed literature. We describe our unique case of a 20 year-old male with spontaneous retroperitoneal perforation of ascending colon resulting in initially retroperitoneal abscess, later converting to scrotal fecal abscess, managed with conservative treatment and drainage of the abscess. 


\section{Case Presentation}

A 20-year-old male presented to the emergency department complaining of gradually increasing noncolicky pain right side abdomen with multiple episodes of nonprojectile vomiting, obstipation, and progressive abdominal distension for the past 3 days. There was fever with chills and rigor for a similar duration. There was no past history of chronic constipation. There was no personal or family history of tuberculosis. At the time of presentation, the patient was having a pulse rate of 110 beats/minute, a blood pressure of $120 / 82 \mathrm{~mm} \mathrm{Hg}$, and a temperature of $39.5^{\circ}$ Celsius. During the abdominal examination, there was tenderness and guarding over the right side of the abdomen with signs of inflammation on the right side back. There was no associated inguinal hernia. On auscultation, bowel sounds were sluggish.

Blood investigations revealed haemoglobin of $11 \mathrm{gm} / \mathrm{dL}$, white cell count of $10,900 /$ cumm with $80 \%$ polymorphs, $16 \%$ lymphocytes, $2 \%$ monocytes, and $2 \%$ eosinophil. Liver function test, renal function test, serum electrolyte, serum glucose, and urine analysis were all normal. Typhi antigen card test was negative.

Abdominal X-ray in the erect position showed the right side minimal pleural effusions with dilated loops of the small bowel. Ultrasonography (USG) of the abdomen reported multiple fluid distended intestinal loops suspecting paralytic ileus/subacute intestinal obstruction. The patient was kept on conservative treatment with Ryle's tube suction, intravenous fluids, and parenteral antibiotics. By the $4^{\text {th }}$ day of conservative treatment, the patient started passing flatus and feces and was gradually shifted to a liquid diet.

On the $8^{\text {th }}$ day of admission, the patient complained of painful swelling right scrotum. Scrotal examination showed signs of inflammation with fluctuation on the right side. CT scan of the abdomen showed discontinuity in the posterior wall of ascending colon with a large retroperitoneal collection having multiple internal air lucencies, displacing ascending colon and caecum medically. The right retroperitoneal collection extending superiorly from right pararenal and posterior perihepatic soft tissue planes to the right iliac fossa and right thigh (Figure 1).

Around $350 \mathrm{ml}$ of fecal contents was evacuated by incision \& drainage (I\&D). The fecal discharge gradually started decreasing while the patient was continued on a liquid diet (Figure 2). The cellulitis of the right side back was also started decreasing. On the 26th day of admission, the patient was discharged in satisfactory condition with no discharge from the scrotal wound. 4-year follow-up was uneventful.

\section{Discussion}

Almost all fecal abscesses/enterocutaneous fistulas of the scrotum are due to incarcerated bowel loop in inguinal hernia. Paediatric age is the prominent group for these abscess/fistula, while adults are comparatively spared [5-7].

After extensive research of indexed literature, we find 33 cases of enterocutaneous fistula/fecal abscess of the scrotum, labia, or inguinal region. In our review, we found that the fecal fistulas/abscesses were either present in below 40 days of age (13 cases, mostly neonates) or above the age of 20 years (17 cases, mostly above 40 years of age) (Table 1$)$. The inguinal hernia was present in all cases except ours, where there was no hernia present. All except two (who refused to operate) were managed by exploratory laparotomy and anastomosis of disrupted bowel, while our case was managed by conservative treatment along with incision \& drainage of the scrotal fecal abscess.

Spontaneous perforation of the colon (SPC) is a perforation of the normal colon in the absence of a pathological cause such as tumours, diverticulosis, or external injury [33]. Colonic perforations are mostly encountered in diverticulitis, carcinoma colon, inflammatory bowel disease, trauma, foreign body insertion, and iatrogenic [34]. The cause of spontaneous colonic perforation is unclear. Hard feces present in patients with chronic constipation compress the colonic wall resulting in diminished blood supply, which may lead to significant feculent ulcer following ischemia and necrosis of colonic mucosa [35].

The posterior colonic perforations are rare causes of retroperitoneal abscess and are relatively seen in frail elderly patients [4]. The retroperitoneum, a potential space with clearly defined boundaries between the peritoneum and the transversalis fascia, can be seeded by infections involving surrounding organs such as kidneys, pancreas, colon, duodenum, bladder, uterus, and rectum [36]. Perforations of bowel in retroperitoneal spaces usually presented with unspecific symptomatology [37], where pyrexia of unknown origin is a common presentation. Less commonly, it may present with pain in the lower back, hip, or thigh. Other symptoms that may be present include malaise, anorexia, and weight loss [38], or painful inguinal swellings [39].

Though it is not the common course, retroperitoneal abscesses may rarely extend to the thigh or scrotum, and such abscesses may be missed to diagnosed for as long as two weeks from the onset of abdominal pain [40]. Infection and air that has developed in retroperitoneal space due to pathology of surrounding organs are contained by transversalis fascia but may rarely dissect away through a deep inguinal ring alongside the spermatic cord in males and the round ligament in women, respectively, to reach scrotum and grand labia when there is tremendous pressure due to their massive size $[41,42]$. The pathophysiological mechanism involved is the emergence of a pressure gradient between the peritoneum and surrounding structures, causing rupture of the perianal tissue, allowing gas from a perforation to diffuse along tissue planes [43]. In our case also, the retroperitoneal abscess was very extensive, occupying almost all possible retroperitoneal space of the right side extending to the thigh and ipsilateral scrotum.

The diagnostic sensitivity of ultrasonography for retroperitoneal abscesses is $67 \%-87 \%$. CT has a sensitivity ranging from $90 \%$ to $100 \%$, while MRI has a sensitivity ranging from $88.5 \%$ to $100 \%$ in diagnosing retroperitoneal abscesses, and both are reliable investigations [44]. 


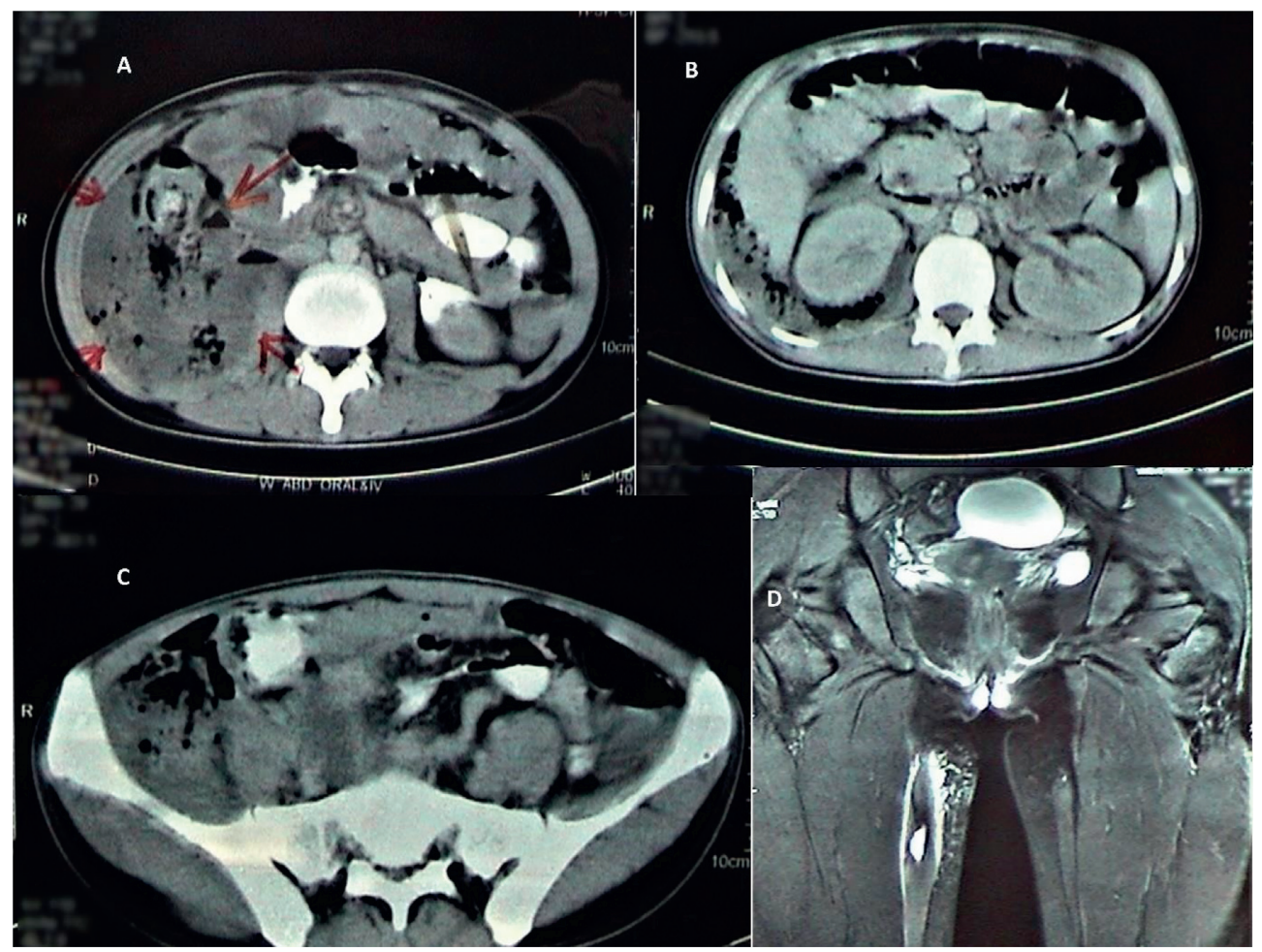

FIGURE 1: CT scan abdomen with oral contrast showed a large retroperitoneal collection with multiple air lucencies displacing ascending colon and caecum medially. (a) Discontinuity in the posterior wall of ascending colon with a large collection having internal air lucencies, (b) collection with internal air lucencies seen in the right pararenal and posterior perihepatic soft tissue planes, (c) retroperitoneal collection seen tracking into the right iliac fossa, and (d) elongated collection and surrounding soft tissue oedema seen along hamstring muscles of the right thigh.

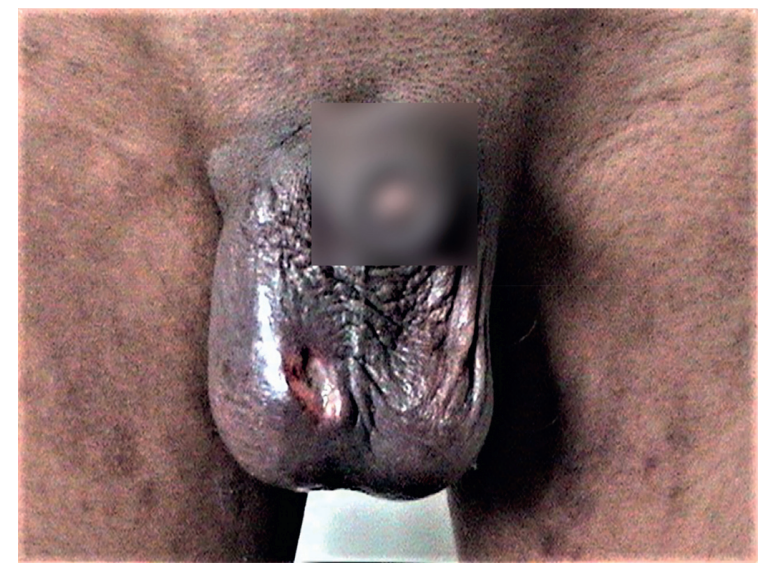

FIGURE 2: Scrotal wound $5^{\text {th }}$ day following drainage of fecal contents.

Further, we found only 12 cases of spontaneous perforation of the colon (SPC) but no case of spontaneous retroperitoneal perforation of ascending colon, or any case of fecal abscess/enterocutaneous fistula of the scrotum in the absence of inguinal hernia and no case of retroperitoneal fecal abscess reaching scrotum in indexed literature. Spontaneous retroperitoneal perforation of ascending colon resulting in retroperitoneal abscess and eventually ending into scrotal fecal abscess in the absence of inguinal hernia was albeit a surprisingly rare case reported in the literature. 
TABLE 1: Review of literature of enterocutaneous fistula (ECF)/fecal abscess of the scrotum.

\begin{tabular}{|c|c|c|c|c|c|c|c|}
\hline $\begin{array}{l}\text { S. } \\
\text { no. }\end{array}$ & Author & $\begin{array}{c}\text { Age } \\
\text { (years) }\end{array}$ & Sex & Clinical presentation & Diagnosis & $\begin{array}{c}\text { Inguinal } \\
\text { hernia }\end{array}$ & Managed by \\
\hline 1 & Rahim et al. [8], 1980 & & $\mathrm{M}$ & $\begin{array}{l}\text { Ulceration and discharge, } \\
\text { scrotum }\end{array}$ & $\begin{array}{l}\text { ECF-inguinal } \\
\text { area }\end{array}$ & Present & Exploratory laparotomy \\
\hline 2 & Rao et al. [9], 1980 & $<1$ & M & $\begin{array}{l}\text { Ulceration and discharge, } \\
\text { scrotum }\end{array}$ & $\begin{array}{l}\text { ECF-inguinal } \\
\text { area }\end{array}$ & Present & Exploratory laparotomy \\
\hline 3 & Rao et al. [9], 1980 & & M & $\begin{array}{l}\text { Iatrogenic fecal fistula, } \\
\text { scrotum }\end{array}$ & $\begin{array}{l}\text { ECF-inguinal } \\
\text { area }\end{array}$ & Present & Exploratory laparotomy \\
\hline 4 & Kapoor et al. [10], 1991 & $<1$ & M & $\begin{array}{l}\text { Ulceration and discharge, } \\
\text { scrotum }\end{array}$ & $\begin{array}{l}\text { ECF-inguinal } \\
\text { area }\end{array}$ & Present & Exploratory laparotomy \\
\hline 5 & Rattan et al. [6], 1998 & $<1$ & M & $\begin{array}{l}\text { Ulceration and discharge, } \\
\text { scrotum }\end{array}$ & $\begin{array}{l}\text { ECF-inguinal } \\
\text { area }\end{array}$ & Present & Exploratory laparotomy \\
\hline 6 & Kasat et al. [11], 2000 & $<1$ & M & $\begin{array}{l}\text { Ulceration and discharge, } \\
\text { scrotum }\end{array}$ & $\begin{array}{l}\text { ECF-inguinal } \\
\text { area }\end{array}$ & Present & Exploratory laparotomy \\
\hline 7 & Ameh et al. [12], 2002 & $<1$ & & Fecal fistula, scrotum & $\begin{array}{l}\text { ECF-inguinal } \\
\text { area }\end{array}$ & Present & Exploratory laparotomy \\
\hline 8 & Ameh et al. [12], 2002 & $<1$ & & Fecal fistula, scrotum & $\begin{array}{l}\text { ECF-inguinal } \\
\text { area }\end{array}$ & Present & Exploratory laparotomy \\
\hline 9 & $\begin{array}{l}\text { Samad and Sheikh [13], } \\
2005\end{array}$ & 25 & M & $\begin{array}{l}\text { Ulceration and discharge, } \\
\text { scrotum }\end{array}$ & $\begin{array}{l}\text { ECF-inguinal } \\
\text { area }\end{array}$ & Present & Exploratory laparotomy \\
\hline 10 & $\begin{array}{c}\text { Koshariya et al. [14], } \\
2006\end{array}$ & & M & $\begin{array}{l}\text { Ulceration and discharge, } \\
\text { scrotum }\end{array}$ & $\begin{array}{l}\text { ECF-inguinal } \\
\text { area }\end{array}$ & Present & Exploratory laparotomy \\
\hline 11 & $\begin{array}{l}\text { Sowande et al. [15], } \\
2006\end{array}$ & $<1$ & $\mathrm{M}$ & $\begin{array}{l}\text { Ulceration and discharge, } \\
\text { scrotum }\end{array}$ & $\begin{array}{l}\text { ECF-inguinal } \\
\text { area }\end{array}$ & Present & Exploratory laparotomy \\
\hline 12 & $\begin{array}{l}\text { Ghritlaharey et al. [7], } \\
2007\end{array}$ & $<1$ & M & $\begin{array}{l}\text { Ulceration and discharge, } \\
\text { scrotum }\end{array}$ & $\begin{array}{l}\text { ECF-inguinal } \\
\text { area }\end{array}$ & Present & Exploratory laparotomy \\
\hline 13 & Sheikh et al. [16], 2009 & 42 & M & $\begin{array}{l}\text { Ulceration and discharge, } \\
\text { scrotum }\end{array}$ & $\begin{array}{l}\text { ECF-inguinal } \\
\text { area }\end{array}$ & Present & Exploratory laparotomy \\
\hline 14 & Chirdan et al. [17], 2010 & 21 & M & $\begin{array}{l}\text { Ulceration and discharge, } \\
\text { scrotum }\end{array}$ & $\begin{array}{l}\text { ECF-inguinal } \\
\text { area }\end{array}$ & Present & Exploratory laparotomy \\
\hline 15 & $\begin{array}{l}\text { Saravana et al. [18], } \\
2010\end{array}$ & 26 & $\mathrm{M}$ & $\begin{array}{l}\text { Ulceration and discharge, } \\
\text { scrotum }\end{array}$ & $\begin{array}{c}\text { ECF-inguinal } \\
\text { area }\end{array}$ & Present & Exploratory laparotomy \\
\hline 16 & $\begin{array}{l}\text { Ohene-Yeboah [19], } \\
2011\end{array}$ & & $\mathrm{M}$ & $\begin{array}{l}\text { Ulceration and discharge, } \\
\text { scrotum }\end{array}$ & $\begin{array}{c}\text { ECF-inguinal } \\
\text { area }\end{array}$ & Present & Exploratory laparotomy \\
\hline 17 & $\begin{array}{l}\text { Ohene-Yeboah [19], } \\
2011\end{array}$ & & M & $\begin{array}{l}\text { Ulceration and discharge, } \\
\text { scrotum }\end{array}$ & $\begin{array}{l}\text { ECF-inguinal } \\
\text { area }\end{array}$ & Present & Exploratory laparotomy \\
\hline 18 & Ezomike et al. [20], 2012 & $<1$ & M & Fecal fistula, scrotum & $\begin{array}{l}\text { ECF-inguinal } \\
\text { area }\end{array}$ & Present & Exploratory laparotomy \\
\hline 19 & Bhasin et al. [21], 2013 & 65 & M & $\begin{array}{l}\text { Iatrogenic fecal fistula, } \\
\text { scrotum }\end{array}$ & $\begin{array}{l}\text { ECF-inguinal } \\
\text { area }\end{array}$ & Present & Exploratory laparotomy \\
\hline 20 & Bhasin et al. [21], 2013 & 40 & M & $\begin{array}{l}\text { Ulceration and discharge, } \\
\text { scrotum }\end{array}$ & $\begin{array}{l}\text { ECF-inguinal } \\
\text { area }\end{array}$ & Present & Exploratory laparotomy \\
\hline 21 & Malik et al. [1], 2014 & 70 & M & $\begin{array}{l}\text { Ulceration and discharge, } \\
\text { scrotum }\end{array}$ & $\begin{array}{l}\text { ECF-inguinal } \\
\text { area }\end{array}$ & Present & Exploratory laparotomy \\
\hline 22 & Ahi et al. [22], 2015 & 62 & M & $\begin{array}{l}\text { Fecal discharge, inguinal } \\
\text { region }\end{array}$ & $\begin{array}{l}\text { ECF-inguinal } \\
\text { area }\end{array}$ & Present & Exploratory laparotomy \\
\hline 23 & Degheili et al. [23], 2015 & 75 & $\mathrm{M}$ & $\begin{array}{l}\text { Post-TAPP inflammatory } \\
\text { swelling scrotum }\end{array}$ & $\begin{array}{l}\text { Fecal abscess- } \\
\text { scrotum }\end{array}$ & Present & Exploratory laparotomy \\
\hline 24 & Ota et al. [24], 2015 & 79 & $\mathrm{M}$ & $\begin{array}{l}\text { Swollen and inflamed, } \\
\text { scrotum }\end{array}$ & $\begin{array}{l}\text { Fecal abscess- } \\
\text { scrotum }\end{array}$ & Present & $\begin{array}{l}\text { Patient refused for } \\
\text { exploratory laparotomy }\end{array}$ \\
\hline 25 & $\begin{array}{l}\text { Panagidis et al. [25], } \\
2015\end{array}$ & $<1$ & M & $\begin{array}{l}\text { Ulceration and discharge, } \\
\text { scrotum }\end{array}$ & $\begin{array}{l}\text { ECF-inguinal } \\
\text { area }\end{array}$ & Present & Exploratory laparotomy \\
\hline 26 & Ajape et al. [26], 2016 & 28 & M & $\begin{array}{l}\text { Ulceration and discharge, } \\
\text { scrotum }\end{array}$ & $\begin{array}{l}\text { ECF-inguinal } \\
\text { area }\end{array}$ & Present & Exploratory laparotomy \\
\hline 27 & Arora [27], 2016 & 35 & M & Fecal fistula, scrotum & $\begin{array}{l}\text { ECF-inguinal } \\
\text { area }\end{array}$ & Present & Exploratory laparotomy \\
\hline 28 & Elenwo et al. [28], 2016 & 61 & $\mathrm{~F}$ & $\begin{array}{l}\text { Ulceration and discharge, } \\
\text { scrotum }\end{array}$ & ECF-labial & Present & Exploratory laparotomy \\
\hline 29 & Hajong et al. [29], 2017 & 53 & M & $\begin{array}{c}\text { Fecal discharge from right } \\
\text { groin }\end{array}$ & $\begin{array}{l}\text { ECF-inguinal } \\
\text { area }\end{array}$ & Present & Exploratory laparotomy \\
\hline
\end{tabular}


TABle 1: Continued.

\begin{tabular}{|c|c|c|c|c|c|c|c|}
\hline $\begin{array}{l}\text { S. } \\
\text { no. }\end{array}$ & Author & $\begin{array}{c}\text { Age } \\
\text { (years) }\end{array}$ & Sex & Clinical presentation & Diagnosis & $\begin{array}{c}\text { Inguinal } \\
\text { hernia }\end{array}$ & Managed by \\
\hline 30 & Raj et al. [30], 2018 & 32 & M & $\begin{array}{l}\text { Ulceration and discharge, } \\
\text { scrotum }\end{array}$ & $\begin{array}{l}\text { ECF-inguinal } \\
\text { area }\end{array}$ & Present & Exploratory laparotomy \\
\hline 31 & Amoako et al. [5], 2018 & 32 & $\mathrm{M}$ & $\begin{array}{l}\text { Ulceration and discharge, } \\
\text { scrotum }\end{array}$ & $\begin{array}{l}\text { ECF-inguinal } \\
\text { area }\end{array}$ & Present & Exploratory laparotomy \\
\hline 32 & Omran et al. [31], 2019 & $<1$ & M & $\begin{array}{l}\text { Swollen and inflamed, } \\
\text { scrotum }\end{array}$ & $\begin{array}{l}\text { Fecal abscess- } \\
\text { scrotum }\end{array}$ & Present & Exploratory laparotomy \\
\hline 33 & Asghar et al. [32], 2020 & 60 & $\mathrm{M}$ & $\begin{array}{l}\text { Ulceration and discharge, } \\
\text { scrotum }\end{array}$ & $\begin{array}{l}\text { ECF-inguinal } \\
\text { area }\end{array}$ & Present & $\begin{array}{l}\text { Patient refused for } \\
\text { exploratory laparotomy }\end{array}$ \\
\hline 34 & $\begin{array}{c}\text { Bahadur et al. (present } \\
\text { case), } 2021\end{array}$ & 20 & M & $\begin{array}{l}\text { Swollen and inflamed, } \\
\text { scrotum }\end{array}$ & $\begin{array}{l}\text { Fecal abscess- } \\
\text { scrotum }\end{array}$ & Absent & $\begin{array}{c}\text { Drainage of the fecal scrotal } \\
\text { abscess }\end{array}$ \\
\hline
\end{tabular}

\section{Conclusion}

Pneumoscrotum and fecal abscess of the scrotum are an extremely rare presentation of retroperitoneal colonic perforation, especially in the absence of inguinal hernia. Diagnosis of retroperitoneal perforation of the colon is often delayed due to the absence of peritoneal irritation. Our experience suggests that, due to extreme pressure, an extensively large retroperitoneal abscess may spread the infection to the scrotum and thigh possibly by dissecting away the transversalis fascia through a deep ring along the side of the spermatic cord. CT scan or MRI performed in undiagnosed case of the acute abdomen can avoid delay in the diagnosis of a retroperitoneal abscess, as well as further spread of infection.

\section{Abbreviations}

SPC: Spontaneous perforation of the colon

USG: Ultrasonography

CT: Computed tomography

MRI: Magnetic resonance imaging

I\&D: Incision \& drainage

ECF: Enterocutaneous fistula.

\section{Data Availability}

All the datasets on which the manuscript relies are available in the Department of Surgery, Dr. Hedgewar Arogya Sansthan.

\section{Consent}

Written informed consent was obtained from the patient for publication of this case report and any accompanying images.

\section{Conflicts of Interest}

The authors declare that they have no conflicts of interest.

\section{Authors' Contributions}

$\mathrm{AB}$ conceptualized the manuscript. $\mathrm{AB}, \mathrm{NS}, \mathrm{MK}, \mathrm{AS}$, and $V G$ reviewed the literature and analysed the data. $A B$ wrote the manuscript with help of NS and MK. AB performed the clinical examination, surgical treatment, and clinical followup. SJ prepared the interpretation of radiological findings. All authors performed final review and editing of the manuscript and approved the final version of the manuscript.

\section{References}

[1] P. Malik, M. Rathi, K. Kumar et al., "Scrotal enterocutaneous fistula: a rare initial presentation of inguinal hernia," Journal of Surgical Case Reports, vol. 2014, no. 6, 2014.

[2] R. Chongxi, J. Jinggang, S. Yan, W. Hongqiao, L. Yan, and Y. Fengshuo, "Spontaneous colonic perforation in adults: evaluation of a pooled case series," Science Progress, vol. 103, no. 3, pp. 1-15, 2020.

[3] S. Al Shukry, "Spontaneous perforation of the colon clinical review of five episodes in four patients," Oman Medical Journal, vol. 24, no. 2, pp. 137-141, 2009.

[4] P. Ruscelli, C. Renzi, A. Polistena, A. Sanguinetti, N. Avenia, and G. Popivanov, "Clinical signs of retroperitoneal abscess from colonic perforation: two case reports and literature review," Medicine (Baltimore), vol. 97, no. 45, Article ID e13176, 2018.

[5] J. K. A. Amoako, T. Wordui, P. K. Kumassah, J. M. Amissah, and M. Ohene-Yeboah, "Entero-scrotal fistula in an adult: a complication of traditional health care practice in Ghana," Clinics in Surgery, vol. 3, no. 1, p. 2025, 2018.

[6] K. N. Rattan and P. Garg, "Neonatal scrotal faecal fistula," Pediatric Surgery International, vol. 13, no. 5-6, pp. 440-441, 1998.

[7] R. K. Ghritlaharey, D. K. Shrivastava, and A. S. Kushwaha, "Spontaneous scrotal faecal fistula in infant: a case report and literature review," Journal of Clinical and Diagnostic Research, vol. 1, pp. 303-306, 2007.

[8] M. Rahim, A. Quadri, and H. Dwivedi, "Scrotal faecal fistula," Journal of Indian Medical Association, vol. 73, pp. 192-194, 1980.

[9] P. L. N. G. Rao, S. K. Mitra, and I. C. Pathak, "Fecal fistula developing in inguinal hernia," The Indian Journal of Pediatrics, vol. 47, no. 3, pp. 253-255, 1980.

[10] R. Kapoor, A. K. Lamba, S. Talwar, M. M. Saha, and N. C. Gupta, "Spontaneous fecal fistula in inguinal hernia," Indian Pediatrics, vol. 28, no. 2, pp. 193-194, 1991.

[11] L. S. Kasat, V. S. Waingankar, T. Kamat, N. A. Not Available, G. Bahety, and I. V. Meisheri, "Spontaneous scrotal faecal fistula in an infant," Pediatric Surgery International, vol. 16, no. 5-6, pp. 443-444, 2000. 
[12] E. Ameh, O. Awotula, and J. Amoah, "Spontaneous scrotal faecal fistula in infants," Pediatric Surgery International, vol. 18, no. 5-6, pp. 524-525, 2002.

[13] A. Samad and G. M. Sheikh, "Spontaneous fecal fistula: a rare presentation of inguinal hernia," Journal of Ayub Medical College Abbottabad, vol. 17, no. 4, pp. 77-79, 2005.

[14] M. Koshariya, S. Naik, and A. Rai, "Incarcerated inguinal hernia presenting as spontaneous scrotal fecal fistula," Hernia, vol. 10, no. 5, pp. 434-435, 2006.

[15] O. Sowande, O. Ogundoyin, and J. Chinda, "Spontaneous scrotal faecal fistula: a rare complication of incarcerated inguinal hernia in infancy," Journal of Indian Association of Pediatric Surgeons (ISSN 0971-9261), vol. 11, no. 4, p. 11, 2006.

[16] M. Sheikh, U. Ashraf, and A. Bashir, "Scrotal enterocutaneous fistula, a rare complication of inguinal hernia, case report and literature review," The Internet Journal of Surgery, vol. 25, no. 2, 2009.

[17] L. Chirdan, A. Uba, D. Iya, and N. Dakum, "Spontaneous scrotal faecal fistula in a neonate: report of a case," Nigerian Journal of Surgical Research, vol. 6, no. 1-2, pp. 2-4, 2010.

[18] S. Rajamanickam, A. Yadav, A. Rai, D. Singh, and A. A. Sonkar, "A complicated true sliding hernia presenting as a spontaneous enteroscrotal fistula in an adult," Journal of Emergencies, Trauma, and Shock, vol. 3, no. 1, pp. 62-65, 2010.

[19] M. Ohene-Yeboah, "Entero-scrotal fistula in a Ghanaian adult: a case report of the spontaneous rupture of a neglected strangulated inguinal hernia," Hernia, vol. 15, no. 4, pp. 455-457, 2011.

[20] U. O. Ezomike, S. O. Ekenze, D. C. Okafor, and E. P. Nwankwo, "Spontaneous scrotal enterocutaneous fistula: a case report and review of literature," Nigerian Journal of Medicine: Journal of the National Association of Resident Doctors of Nigeria, vol. 21, no. 1, pp. 111-112, 2012.

[21] S. K. Bhasin, V. Kumar, S. L. Kachroo, G. G. Bali, and M. Mahajan, "Enterocutaneous fistula of the scrotum," JK Science, vol. 15, no. 3, pp. 145-147, 2013.

[22] K. S. Ahi, A. Moudgil, K. Aggarwal, C. Sharma, and K. Singh, "A rare case of spontaneous inguinal faecal fistula as a complication of incarcerated Richter's hernia with brief review of literature," BMC Surgery, vol. 15, no. 1, pp. 1-5, 2015.

[23] J. A. Degheili, M. Aboul Hosn, M. El Lakis, and A. H. Hallal, "Sigmoid to scrotal fistula secondary to mesh erosion: a rare complication of inguinal hernia repair in a patient on anticoagulation," BMC Surgery, vol. 15, p. 94, 2015.

[24] S. Ota, T. Noguchi, T. Takao et al., "An incarcerated colon inguinal hernia that perforated into the scrotum and exhibited an air-fluid level," Case Reports in Medicine, vol. 2015, Article ID 105183, 3 pages, 2015.

[25] A. Panagidis, X. Sinopidis, K. Zachos et al., "Neonatal perforated Amyand's hernia presenting as an enterocutaneous scrotal fistula," Asian Journal of Surgery, vol. 38, no. 3, pp. 177-179, 2015.

[26] A. A. Ajape, M. D. Adesina, I. O. Olaoye, and A. K. Arogundade, "Spontaneous scrotal faecal fistula in a Nigerian adult: review of literature and proposal for management protocol," Promoting Access to African Research, vol. 93, no. 10, pp. 6-10, 2016.

[27] B. Arora, "Scrotal fecal fistula due to enteric perforation in inguinal hernia," International Journal of Case Reports Images, vol. 7, no. 12, pp. 791-794, 2016.

[28] S. N. Elenwo, P. O. Igwe, R. S. Jamabo, and U. S. Sonye, "Spontaneous entero-labial fistula complicating Richters hernia: report of a case," International Journal of Surgery Case Reports, vol. 20, pp. 27-29, 2016.
[29] R. Hajong, D. Khongwar, O. Komut, N. Naku, and K. Baru, "Spontaneous enterocutaneous fistula resulting from richter's hernia," Journal of Clinical and Diagnostic Research, vol. 11, no. 8, pp. PD05-PD06, 2017.

[30] P. Raj, H. Birua, and V. Prasad, "Enteroscrotal fistula in a neonate following incarcerated inguinal hernia," Journal of Neonatal Surgery, vol. 6, 2017.

[31] A. Omran, B. S. Gawrieh, A. Abdo, M. Ali Deeb, M. A. Khalil, and W. Shater, "Amyand hernia: scrotal pyocele, associated with perforated vermiform appendix and complicated by testicular ischemia in neonate," Journal of Surgery Case Reports, vol. 2019, no. 9, Article ID rjz265, 2019.

[32] M. S. Asghar, A. Kaleem, and S. Rijal, "A rare case of spontaneous scrotal enterocutaneous fistula as a complication of incarcerated inguinal hernia with review of literature," The Professional Medical Journal, vol. 27, no. 7, pp. 1537-1540, 2020.

[33] M. J. Zhang and J. B. Wu, "Treatment of spontaneous perforation of the large intestine: a report of 9 cases," Chinese Journal of General Surgery, vol. 32, pp. 836-839, 2002.

[34] J. C. Goligher, Surgery of the Anus, Rectum and Colon, pp. 924-925, Bailliere Tindall, London, UK, 1980.

[35] B. Yang and H.-K. Ni, "Diagnosis and treatment of spontaneous colonic perforation: analysis of 10 cases," World Journal of Gastroenterology, vol. 14, no. 28, pp. 4569-4572, 2008.

[36] A. W. Meshikhes, M. M. Al-Otaibi, H. A. Al-Amer, and O. H. Al-Saif, "Retroperitoneal abscess as an initial presentation of cecal carcinoma," Saudi Medical Journal, vol. 23, no. 8, pp. 999-1001, 2002.

[37] J. Singh, M. Steward, T. Booth, H. Mukhtar, and D. Murray, "Evolution of imaging for abdominal perforation," The Annals of The Royal College of Surgeons of England, vol. 92, no. 3, pp. 182-188, 2010.

[38] M. Paley, P. S. Sidhu, R. A. Evans, and J. B. Karani, "Retroperitoneal collections-aetiology and radiological implications," Clinical Radiology, vol. 52, no. 4, pp. 290-294, 1997.

[39] J. L. Rivera-Herrera, J. N. Otheguy, J. Nieves-Ortega, and R. F. Fortuño, "Painful inguinal mass: uncommon presentation of a retroperitoneal abscess," Bulletin of the Porto Rico Medical Association, vol. 83, no. 9, pp. 402-403, 1991.

[40] U. G. H. Ishan, M. C. K. Thilakasiri, P. N. Weeratunga, and R. D. Lanerolle, "Successful medical management of a retroperitoneal abscess: a difficult diagnosis in pyrexia of unknown origin," Case Reports in Infectious Diseases, vol. 2020, Article ID 6174293, 5 pages, 2020.

[41] J. F. Mastromatteo, H. J. Mindell, M. F. Mastromatteo, M. B. Magnant, N. V. Sturtevant, and W. P. Shuman, "Communications of the pelvic extraperitoneal spaces and their relation to the abdominal extraperitoneal spaces: helical CT cadaver study with pelvic extraperitoneal injections," Radiology, vol. 202, no. 2, pp. 523-530, 1997.

[42] P. R. Bhosale, M. Patnana, C. Viswanathan, and J. Szklaruk, "The inguinal canal: anatomy and imaging features of common and uncommon masses," Radiographics, vol. 28, no. 3, pp. 819-835, 2008.

[43] I. B. Amor, R. Kassir, E. Bachir, H. Katharina, T. Debs, and J. Gugenheim, "Perforated diverticulitis of the sigmoid colon revealed by a perianal fistula," International Journal of Surgery Case Reports, vol. 2015, no. 8C, pp. 73-75, 2015.

[44] G. M. Varghese, P. Trowbridge, and T. Doherty, "Investigating and managing pyrexia of unknown origin in adults," British Medical Journal, vol. 341, Article ID C5470, 2010. 